\title{
Effect of Age at First Calving on First Lactation Milk Yield in Holstein Cows from Costa Rican Specialized Dairy Herds
}

\author{
Mauren Salazar-Carranza1, Gloriana Castillo-Badilla ${ }^{2 *}$, Jaime Murillo-Herrera1, \\ Frank Hueckmann-Voss ${ }^{1}$, Juan José Romero-Zúñiga ${ }^{2,3}$ \\ ${ }^{1}$ Private Consultant \\ ${ }^{2}$ Herd Health and Production Control Department, School of Veterinary Medicine, Universidad Nacional, \\ Heredia, Costa Rica \\ ${ }^{3}$ Population Medicine Research Program, School of Veterinary Medicine, Universidad Nacional, Heredia, \\ Costa Rica \\ Email: mausalazarcarranza@gmail.com, ${ }^{*}$ gloriana.castillo.badilla@una.cr, jmurillo80@gmail.com, \\ huecsedo@hotmail.com, juan.romero.zuniga@una.cr
}

Received 25 July 2014; revised 10 August 2014; accepted 20 August 2014

Copyright (C) 2014 by authors and Scientific Research Publishing Inc.

This work is licensed under the Creative Commons Attribution International License (CC BY). http://creativecommons.org/licenses/by/4.0/

c) (7) Open Access

\begin{abstract}
In order to determine the effect of age at first calving (AFC) at 305-d milk yield, a historical prospective longitudinal study of 46,029 pure specialized dairy Costa Rican Holstein animals was carried out between 2000 and 2010. Data on purebred specialized dairy Holstein cows enrolled in the program VAMPP Bovino 3.0 were included. Information was analyzed by using descriptive statistics and mixed linear models. The effect of the AFC was adjusted to the ecological zone, season of birth, year of birth, inbreeding index, and type of parturition and parity number of the dam at birth. The average AFC for the animals that were part of the study was 30.7 mo (SD: 6.8, 95\% CI: 30.6 - 30.7). The average total milk production in the first lactation was $5188.0 \mathrm{~kg}$ (95\% CI: 5153.4 - 5223.2), whereas the 305-d corrected milk yield resulted in 5288 kg (95\% CI: 5253.7 - 5323.2 ). Cows with AFC less than 26 mo and between 26.0 and 33.6 mo, produced $-354.8 \mathrm{~kg} / 305-\mathrm{d}$ (P < $0.0001)$ and $-105.6 \mathrm{~kg} / 305-\mathrm{d}(\mathrm{P}=0.0117)$ respectively, compared with cows calving over $33.6 \mathrm{mo}$. It is likely that the observed effect of the AFC on the topmost dairy lactation affects the productive life of the cow within the herd. Further studies are required to prove this hypothesis.
\end{abstract}

\section{Keywords}

Tropics, Holstein, Production, Reproduction, Information Systems

\footnotetext{
Corresponding author.
}

How to cite this paper: Salazar-Carranza, M., Castillo-Badilla, G., Murillo-Herrera, J., Hueckmann-Voss, F. and RomeroZúñiga, J.J. (2014) Effect of Age at First Calving on First Lactation Milk Yield in Holstein Cows from Costa Rican Specialized Dairy Herds. Open Journal of Veterinary Medicine, 4, 197-203. http://dx.doi.org/10.4236/ojvm.2014.49023 


\section{Introduction}

Reducing the production costs is becoming more important in the dairy industry. The suitable development of replacement heifers is an expensive investment for dairy farms, so estimations of all associated costs are about $20 \%$ of the total production costs [1].

The age at first calving (AFC) reflects the rate of growth of the female. A late entry in the productive life reduces the economic value of the animals, due to the potentially decreased number of offspring produced in their lifetime [2]. This parameter, considered as primary on herd health programs may be influenced by body size and the onset of hormonal activity of the reproductive system [2].

In the United States, the average of AFC in dairy cows (mostly Holstein), between 1985 and 1990, was 25.9 mo [1]. Currently, breeding programs for cow replacement seeks for an average age at first calving of around 24 mo to decrease the production costs [1]. Greater the number of calves and the amount of milk produced per year of life, greater the productivity in the herd [3]. Thus, an AFC beyond 25 mo is not cost-effective and it is recommended that the heifers have their first calf between 23 and 25 mo of age [3].

Studies on Holstein cows carried out in Italy, USA and Peru prove that cows calving at a young age have lower milk production during their first lactation, however, their total production per day and their performance during their lifetime is significantly greater than those animals who had their first birth at a later age [1] [4].

For Holstein cows in the U.S., the information about the AFC effect on milk production in first lactation is variable. Some authors have not observed positive effect [5] while others have found a negative effect [6]. Studies suggest that the reduction in AFC averaging from 24.7 mo to 21.9 mo results in a reduction in milk production in the first lactation [6].

Studies in the tropics indicate that milk production systems with Holstein breed animals are limited in their milk production level by both genetic and environmental factors. Tropical environmental conditions affect the productive performance of dairy cows, decreasing production and limiting the expression of their genetic potential [7]. Thus, studies in replacement heifers conclude, that milk production during the first lactation is influenced by the growth rate during the rearing stage, with a significant and positive linear association between the AFC and milk production during the first lactation [8]. These results may be influenced by the higher body condition score at first birth, influencing positively on milk production in the subsequent lactation.

The selection of animals for first service, based on the age, is an effective strategy for dairy producers to improve the economic performance of their herds, because this can affect positively or negatively the milk production, fat percentage, longevity and productive life. Therefore, identifying the AFC for each farm in terms of milk production can be very profitable to streamline the costs of raising heifers, as long as this measure does not impair reproductive efficiency.

Based on this, the objective of this study was to determine the effect of age at first calving on first lactation production in specialized Holstein dairy cows from Costa Rica.

\section{Materials and Methods}

\subsection{Population and Study Design}

A longitudinal prospective-historical study with data from 46,029 pure Holstein cows in specialized dairy Costa Rican herds was performed during the period 2000-2010. The animals were registered in the program VAMPP Bovine 3.0 (Veterinary Automated Program for Management and Population Control) [9] in the Regional Informatics Center for Sustainable Animal Production (CRIPAS), School of Veterinary Medicine of the National University (EMV-UNA), Costa Rica.

The 305-d milk production $(\mathrm{kg} / 305-\mathrm{d})$ of the first lactation was the dependent variable, being the age at first calving (AFC) the main independent variable. Both dependent and independent variables and the way they were used for the analysis of first lactation are described in Table 1.

\subsection{Data Analysis}

Data analysis consisted of two phases:

1) Descriptive statistics. Measures of central tendency (mean and median) and dispersion (standard deviation and standard error) for continuous variables were calculated. Also percentages for discrete variables were calculated. The confidence interval (CI) at $95 \%$ was determined for both types of measures. 
Table 1. Multivariate analysis for the variables of time, place and animal on the production at 305 days of first lactation.

\begin{tabular}{|c|c|c|c|c|c|}
\hline Variable & Stratum & Estimate & Difference & $\mathrm{SE}^{*}$ & $\mathrm{P}^{* *}$ \\
\hline Constant & & & 4982.05 & 193.40 & $<0.0001$ \\
\hline \multirow[t]{3}{*}{$\mathrm{AFC}$ (months) } & $<26$ & 4817.36 & -354.78 & 46.50 & $<0.0001$ \\
\hline & $26-33.6$ & 5066.54 & -105.60 & 41.87 & 0.0117 \\
\hline & $>33.6$ & 5172.14 & 0 & 0 & 0 \\
\hline \multirow[t]{7}{*}{ Zone $^{* * *}$} & LM-wf & 5432.86 & 1311.38 & 175.72 & $<0.0001$ \\
\hline & P-wf & 5393.09 & 1271.61 & 169.17 & $<0.0001$ \\
\hline & P-vwf & 4650.61 & 529.13 & 179.00 & 0.0031 \\
\hline & T-vwf & 5264.67 & 1143.18 & 167.29 & $<0.0001$ \\
\hline & LM-rf & 4703.54 & 582.06 & 169.24 & 0.0006 \\
\hline & P-rf & 5564.53 & 1443.04 & 172.42 & $<0.0001$ \\
\hline & M-vwf & 4121.48 & 0 & 0 & 0 \\
\hline \multirow[t]{4}{*}{ Type of parturition ${ }^{* * * *}$} & Normal & 5058.29 & 79.21 & 53.95 & 0.1421 \\
\hline & Distocic & 4979.08 & 0 & 0 & 0 \\
\hline & Without RFM & 5115.72 & 194.08 & 81.13 & 0.0168 \\
\hline & With RFM & 4921.64 & 0 & 0 & 0 \\
\hline First lactation length & $<256$ & 3648.58 & -2281.33 & 40.85 & $<0.0001$ \\
\hline \multirow[t]{2}{*}{ (days) } & $256-375$ & 5477.55 & -452.36 & 27.51 & $<0.0001$ \\
\hline & $>375$ & 5929.91 & 0 & 0 & 0 \\
\hline \multirow[t]{2}{*}{ Inbreeding coefficient } & $<6.25 \%$ & 5086.16 & 134.94 & 57.7 & 0.0196 \\
\hline & $\geq 6.25 \%$ & 4951.20 & 0 & 0 & 0 \\
\hline
\end{tabular}

${ }^{*} \mathrm{SE}=$ difference standard error, ${ }^{* *} \mathrm{P}=\mathrm{P}$ value of difference, ${ }^{* * *} \mathrm{LM}-\mathrm{vw}=$ Lower Montane-wet forest; P-wf $=$ Premontane-wet forest; P-vwf $=$ Premontane-very wet forest; T-vwf $=$ Tropical-very wet forest; LM-rf = Lower Montane-rain forest; P-rf = Premontane-rain forest; M-vwf = Montane-very wet forest. ${ }^{* * * *}$ Type of parturition: Normal = Normal without assistance; Normal with RFM = Normal without assistance with FMR; Distocic: Difficult with assistance and without cesarean; Distocic with RFM = Difficult with assistance without cesarean and with RFM; Cesarean = Cesarean.

2) Assessment of the effect of AFC on kg 305-d using a multiple linear mixed-effect regression model (PROC MIXED, SAS/STAT see. 9.2, SAS Institute Inc. SAS $\left.{ }^{8}\right)$ [10].

The statistical model used to estimate the absolute effect of the AFC on the first lactation 305-d milk production:

$$
\text { Yijklm }=\mu 0+A \text { c }_{i}+\text { hys }_{j}+\text { eco }_{k}+\text { lactmother }_{l}+\text { birthtype }_{m}+\text { inbreed }_{o}+\text { eijklmno }
$$

where:

Yijklm $=$ Milk production $(\mathrm{kg} / 305-\mathrm{d})$ at the first lactation

$\mu 0=$ Overall mean

$A f c_{i}=$ fixed effect of age at first calving (months)

$H a e_{j}=$ random effect of the herd/year/calving season (or birth AFC)

$e c o_{k}=$ fixed effect of ecozone $(k: 1-9)$ (according to Holdridge, 1987)

lactmother $r_{l}=$ fixed effect of lactations number of the mother

birthtype $_{m}=$ fixed effect of type of parturition (normal, dystocia [with/without fetal membrane retentionFMR])

inbreed $_{n}=$ fixed effect of the level of inbreeding (low: $<6.25 \%$ - high: $\geq 6.25 \%$ )

eijklmn $=$ random residual effect

Statistical analyzes were performed using SAS version 9.2 [10].

\section{Results}

The average AFC for the study population is $30.7 \mathrm{mo}$ (SD: 6.8, 95\% CI $30.7-30.8$ ) with a median of 28.9. The average total milk production in the first lactation was $5188 \mathrm{~kg}$. (95\% CI: 5153.4 - 5223.2), while 305-d milk yield corresponded to $5288 \mathrm{~kg}$ (95\% CI: 5253.7 - 5323.2). 
The AFC had a highly significant association with the first lactation at 305-d milk yield. Cows whose first birth occurs before $26 \mathrm{mo}$ and those that calve between 26 and 33.6 mo. show a difference of $-354.78 \mathrm{~kg}(\mathrm{P}<$ $0.0001)$ and $-105.6 \mathrm{~kg}(\mathrm{P}=0.0117)$ respectively, compared to cows calving over the $33.6 \mathrm{mo}$ (Table 1$)$.

In the case of the variable ecozone, meaning the relationship between the annual temperature, annual precipitation and humidity, that allows the characterization of the weather in a specific geographic area [11]; and taking the montane wet forest $(\mathrm{M}-\mathrm{wf})$ area as a point of comparison, there was a significant production difference $(\mathrm{P}<$ 0.0001 ) higher than $+1000 \mathrm{~kg}$ compared to other areas, except in premontane wet forest (P-wf) and lower montane rain forest (LM-rf); areas in which the difference is smaller but still higher than $+500 \mathrm{~kg}$ (Table 1).

When analyzing the effect of the reproductive variables on the milk yield, there was a significant difference of $+194.08 \mathrm{~kg}(\mathrm{P}<0.05)$ in cows that did not show fetal membrane retention (FMR) compared to those which presented such condition.

On the other hand, there is a significant difference of $+134.96 \mathrm{~kg}$ in the $305-\mathrm{d}$ milk yield in cows with an inbreeding coefficient $<6.25 \%$, regarding those with an inbreeding coefficient $\geq 6.25 \%$ (Table 1 ).

\section{Discussion}

\section{Age at First Calving}

The mean of the AFC assessed in this study for pure Holstein cows, in different specialized Costa Rican dairy herds was $30.6 \mathrm{~m}$. During a study performed by Cedeño and Vargas [12]; in the period from 1998 to 2005, the value of AFC remained between 30 and 31 mo. In the years of 2006 and 2007, it showed a tendency to decrease to 29 and 28 mo respectively. The average of AFC observed is higher than those reported for the Holstein pure breed in countries like the United States (25.9 mo [13]), Italy (26 mo [14]), Iran (26.8 mo [3]), Spain (28.6 mo [15]), and Colombia (26.72 mo [16]), under template weather. The result obtain by this study, can be attributed to the heifer rearing based on forage consumption, without any mineral supplementation, that causes a limitation on the growth index and in the development of the animal, influencing a high AFC [17] [18].

In the current study, the average for the 305-d milk yield at first lactation corresponded to $5288.0 \mathrm{~kg}$ ( \pm 1569.4 ), being similar to the average reported for Colombia of $5761 \pm 1735 \mathrm{~kg}$ [19]. This result is higher to that the one reported by Molina and Boschini [20] in a production corrected to $305 \mathrm{~d}$ of $4053.78 \pm 850.5 \mathrm{~kg}$ and to the obtained by Carvajal et al. [7] in their study in Holstein cows in Yucatán, Mexico, where the overall average milk production during the first lactation was $2918.3 \pm 67.6 \mathrm{~kg}$ and up to $305 \mathrm{~d}$ of $2635 \pm 51.9 \mathrm{~kg}$, but in conditions of high temperature and environmental humidity. However, this value is much lower than the observed in USA (11920 kg; [21]) and Iran (7082 kg; [22]) for this breed. These differences in the milk yield performance, regarding other countries, are due to the fact that Holstein breed has the potential to produce important volumes of milk, however, in tropical environmental conditions this is quite limited [7]. Moreover, the animals are managed under different geographical zones (altitudes), weather and management conditions such as nutrition, production system (grazing vrs. stabled) and the number of milking periods to which cows undergo in a day. All of these factors are reflected in the milk yield of each cow.

A significant effect of AFC on milk production at first lactation was determined. The cows with low and medium AFC showed a decrease of $354.78 \mathrm{~kg}$ and $105.60 \mathrm{~kg}$ in their production compared to cows with AFC > $33.6 \mathrm{mo}$. This is consistent to a previous study [1] indicating a decrease in milk production at the first lactation with $\mathrm{AFC}<25 \mathrm{mo}$, and higher production as the AFC increases [6]. Although it differs from that reported by Rodriguez and Martinez [23], where the AFC did not affect the production of the first lactation. On the other hand, Nilforooshan and Edriss [3] indicate that the AFC can significantly affect milk production, fat percentage, lifetime and productive life. Regarding this matter, Pirlo et al. [1] mention that the negative effect of a low AFC on milk production could be caused by different factors: such as overweight before puberty and a low body score condition in heifers, at the beginning of first lactation.

When analyzing the effect of the variable ecozone, areas with higher production rates correspond to the premontane very wet forest (P-vwf); low montane wet forest (LM-wf); the premontane wet forest (P-wf), and the tropical wet forest (T-wf) [24]. These agro ecological areas are characterized by temperatures $\leq 24^{\circ} \mathrm{C}$, an altitude between 500 and 2000 m.a.s.l. and rainfall ranging 1000 to $2000 \mathrm{~mm}$ annually, except to premontane wet forest (P-wf) and to tropical wet forest (T-wf) areas which differ in precipitation ( $4000 \mathrm{~mm} /$ year) (Table 2).

These tropical conditions favor a suitable grass growth, especially protein-rich grass. This characteristic benefits the production performance of the animals, but despite of that, the temperature and relative high humidity 
Table 2. Variation ranges of altitude, precipitation and temperature in Costa Rican agro ecological zones with presence of milk production systems.

\begin{tabular}{|c|c|c|c|c|}
\hline Agroecologicalzone & Code & $\begin{array}{l}\text { Altitude } \\
\text { (masl) }\end{array}$ & $\begin{array}{l}\text { Precipitation } \\
\text { (mm/year) }\end{array}$ & $\begin{array}{c}\text { Average annual } \\
\text { Temperature }\left({ }^{\circ} \mathrm{C}\right)\end{array}$ \\
\hline Tropical-dryforest & T-df & $0-500$ & $1000-2000$ & $>24$ \\
\hline Tropical-very wet forest & T-vwf & $0-500$ & $4000-8000$ & $>24$ \\
\hline Premontane-very wet forest & P-vwf & $500-1500$ & $2000-4000$ & $18-24$ \\
\hline Lower Montane-wetforest & LM-wf & $1500-2000$ & $1000-2000$ & $12-17$ \\
\hline Lower Montane-rain forest & LM-rf & $1500-2000$ & $4000-8000$ & $12-17$ \\
\hline Tropical-wetforest & T-wf & $0-500$ & $2000-4000$ & $>24$ \\
\hline Premontane-wetforest & P-wf & $500-1500$ & $1000-2000$ & $18-24$ \\
\hline Lower montane-very wet forest & LM-vwf & $1500-2000$ & $2000-4000$ & $12-17$ \\
\hline Montane-very wet forest & M-vwf & $2000-2500$ & $1000-2000$ & $6-11$ \\
\hline
\end{tabular}

Based on Holdridge (1987).

are conditions that affect the expression of genetic potential of animals and compromise their welfare [25].

Likewise, the less production areas are premontane wet forest (P-wf) and lower montane rain forest (LM-rf), characterized with rainfalls of $4000-8000 \mathrm{~mm} /$ year and temperatures from $12^{\circ} \mathrm{C}$ to $24^{\circ} \mathrm{C}$.

Among the environmental conditions related to productivity are the temperature [26], the relative humidity [27], the solar radiation [28], the wind speed [29], the length of day [30] and the daily rainfall [31]. In this case, the high precipitation could be one of the most important factors contributing to declining milk production in these areas, where the highly acidic soil, poor in microelements and low fertility, limiting the suitable growth and the protein content of the pastures [32].

Tropical grasses are in disadvantaged regarding to those in temperate climate, because the high temperatures and the significant exposure to diseases and predators are responsible for high levels of nitrates and low lignin, protein and non-fibrous carbohydrates, qualities that make nutritional values average to low. Another aspect that reduces the quality of tropical forages is the adaptation to geographical areas with long nights during which soluble carbohydrates are oxidized, resulting in a low ratio between the non-fibrous carbohydrate and degradable protein. This condition reduces microbial protein synthesis in ruminants consuming these pastures [33].

The effect of variation AFC on production costs appeared to have a negative effect on first lactation milk yield and fat percentage, when a reduction of AFC; however, it has a positive effect on milk protein percentage [1]. According to Pirlo et al. [1] reduction of age at first calving below 26 mo of age consistently produced a positive effect on the difference between milk yield returns and rearing costs per heifer in about $\$ 57.8$ and in $\$ 62$ if age at calving was 22 . The biological limitations of reducing dramatically the AFC should be considered.

\section{Conclusion}

During the development of the study, a lineal effect of AFC on dairy lactation in Holstein cows was determined. A reduction of AFC leads to a depletion of milk production, probably affecting the genetic potential of the animal, and its longevity within the herd. Further studies are required to prove this hypothesis.

\section{Acknowledgements}

We express our gratitude to the milk producers in Costa Rica who use the Bovine VAMPP program and offer their data to CRIPAS for research population. Also, we thank Gina Isela Villegas for her assistance in reviewing the final document style.

\section{References}

[1] Pirlo, G., Miglior, F. and Speroni, M. (2000) Effect of Age at First Calving on Production Traits and on Difference between Milk Yield Returns and Rearing Costs on Italian Holsteins. Journal of Dairy Science, 83, 603-608. http://dx.doi.org/10.3168/jds.S0022-0302(00)74919-8

[2] Grajales, H., Hernández, A. and Prieto, E. (2006) Edad y peso a la pubertad y su relación con la eficiencia repro- 
ductiva de grupos raciales bovinos en el trópico colombiano. Livestock Research for Rural Development, 18. http://www.lrrd.org/lrrd18/10/graj18139.htm

[3] Nilforooshan, M.A. and Edriss, M.A. (2004) Effect of Age at First Calving on Some Productive and Longevity Traits in Iranian Holsteins of the Isfahan Province. Journal of Dairy Science, 87, 2130-2135. http://dx.doi.org/10.3168/jds.S0022-0302(04)70032-6

[4] Marini, P.R., Charmandarian, A. and Di Masso, R.J. (2007) Desempeño productivo y reproductivo de vacas de diferentes edades al primer parto en sistemas a pastoreo. Sitio Argentino de Producción Animal. http://www.produccion-animal.com.ar/

[5] Gardner, R.W., Smith, L.W. and Park, R.L. (1988) Feeding and Management of Dairy Heifers for Optimal Lifetime Productivity. Journal of Dairy Science, 71, 996-999. http://dx.doi.org/10.3168/jds.S0022-0302(88)79646-0

[6] Ettema, J. and Santos, J. (2004) Impact of Age at First Calving on Lactation, Reproduction, Health, and Income in First-Parity Holstein on Commercial Farms. Journal of Dairy Science, 87, 2730-2742. http://dx.doi.org/10.3168/jds.S0022-0302(04)73400-1

[7] Carvajal, M., Valencia, E.R. and Segura, J.C. (2002) Duración de la lactancia y producción de leche de vacas Holstein en el Estado de Yucatán México. Rev Biomed, 13, 25-31.

[8] Casas, E. and Tewolde, A. (2001) Evaluación de características relacionadas con la eficiencia reproductiva. Archivos latinoamericanos de Producción Animal, 9, 63-67.

[9] Noordhuizen, J.P.T.M. and Buurman, J. (1984) VAMPP: A Veterinary Automated Management and Production Control Program for Dairy Farms (The Application of MUMPS for Data Processing). Veterinary Quarterly, 6, 66-72. http://dx.doi.org/10.1080/01652176.1984.9693914

[10] SAS Institute Inc., SAS ${ }^{\circledR}$ (1990) User's Guide. Version 6, 4th Edition, SAS Institute Inc., Cary, 943 p.

[11] Holdrige, L.R. (1987) Ecología basada en zonas de vida. IICA, San José.

[12] Cedeño, D.A. and Vargas, L.B. (2004) Efecto de la raza y el manejo sobre la vida productiva del bovino lechero en Costa Rica. Archivos de Zootecnia, 53, 129-140.

[13] Heinrichs, A.J., Wells, S.J., Hurd, H.S., Hill, G.W. and Dargatz, D.A. (1994) The National Dairy Heifers Evaluation Project: A Profile of Heifer Management Practices in the United States. Journal of Dairy Science, 77, 1548-1555. http://dx.doi.org/10.3168/jds.S0022-0302(94)77096-X

[14] Pirlo, G. (1997) Rearing Cost of Replacement Heifer and Optimal Age at First Calving. L Informatore Agrario, 9-12.

[15] Perez, M.A., Hernandez, D., Alenda, R., Carabano, M.J. and Charfeddine, N. (1999) Genetic Analysis of True Profit for Spanish Dairy Cattle. http://www.interbull.slu.se/bulletins/bulletin23/perez.pdf

[16] Bolívar, D.M., Echeverry, J.J., Restrepo, L.F. and Muñoz, M.F.C. (2009) Productividad de vacas Holstein y Jersey en una zona de bosque húmedo montano bajo (Bh-MB). Livestock Research for Rural Development, Vol. 21, Article No. 80. http://www.lrrd.org/lrrd21/6/boli21080.htm

[17] Hussein, M.M., Agawany, A.A.E. and Khalil, A.A.Y. (2009) Influence of Subclinical Mastitis on Some Reproductive Parameters in Holstein-Friesian Dairy Cows. Veterinary Medical Journal Giza, 57, 97-113.

[18] Heinrichs, A.J., Heinrichs, B.S., Harel, O., Rogers, G.W. and Place, N.T. (2005) A Prospective Study of Calf Factors Affecting Age, Body Size, and Body Condition Score at First Calving of Holstein Dairy Heifers. Journal of Dairy Science, 88, 2828-2835. http://dx.doi.org/10.3168/jds.S0022-0302(05)72963-5

[19] Muñoz, M.F.C., Tonhati, H., Costa, C. and Benavides, F. (2001) Interacción genotipo-ambiente en ganado Holstein colombiano. Asociación Latinoamericana de Producción Animal, 2, 74-78.

[20] Molina, R. and Boschini, C. (1979) Ajuste de la curva de lactancia de ganado Holstein con un modelo lineal. Tesis. Escuela de Zootecnia. Universidad de Costa Rica, San José, 167.

[21] Animal Improvement Program Laboratory (A.I.P.L.) United States Department of Agriculture. Agricultural Research Service. http://www.aipl.arsusda.gov/

[22] Rokouei, M., Torshimi, R.V., Shahrbabak, M.M., Sargolzaei, M. and Sorencen, A.C. (2010) Monitoring Inbreeding Trends and Inbreeding Depression for Economically Important Traits of Holstein Cattle in Iran. Journal of Dairy Science, 93, 3294-3302. http://dx.doi.org/10.3168/jds.2009-2748

[23] Rodríguez, G. and Martínez, G.E. (2008) Efecto de la Edad al Primer Parto, Grupo Racial y Algunos Factores Ambientales sobre la Producción de Leche y el Primer Intervalo entre Partos en Vacas Doble Propósito. Archivos de Medicina Veterinaria, 40, 7-22.

[24] Monge, R.Q. (2007) Memorias del IX Congreso Nacional de Ciencias: Exploraciones fuera y dentro del aula. Bosques de Costa Rica. Ago. 24 y 25. Instituto Tecnológico de Costa Rica, Cartago.

[25] Kadzere, C., Murphy, M., Silanikove, N. and Maltz, E. (2002) Heat Stress in Lactating Dairy Cows: A Review. Lives- 
tock Production Science, 77, 59-91. http://dx.doi.org/10.1016/S0301-6226(01)00330-X

[26] Settivari, R., Spain, J., Ellersieck, M., Byatt, J., Collier, R. and Spiers, D. (2007) Relationship of Thermal Status to Productivity in Heat-Stressed Dairy Cows Given Recombinant Bovine Somatotropin. Journal of Dairy Science, 90, 1265-1280. http://dx.doi.org/10.3168/jds.S0022-0302(07)71615-6

[27] Bohmanova, J., Misztaland, I. and Cole, J. (2007) Temperature-Humidity Indices as Indicators of Milk Production Losses Due to Heat Stress. Journal of Dairy Science, 90, 1947-1956. http://dx.doi.org/10.3168/jds.2006-513

[28] Tucker, C., Rogers, A. and Schutz, K. (2007) Effect of Solar Radiation on Dairy Cattle Behaviour, Use of Shade and Body Temperature in Pasture-Based System. Applied Animal Behaviour Science, 109, 141-154. http://dx.doi.org/10.1016/j.applanim.2007.03.015

[29] Nassuna-Musoke, G., Kabassa, J. and King, M. (2007) Response of Friesian Cows to Microclimate on Small Farms in Warm Tropical Climates. Journal of Animal and Veterinary Advances, 6, 899-906.

[30] Barash, H., Silanikove, N., Shamay, A. and Ezra, E. (2001) Interrelationships among Ambient Temperature, Day Length and Milk Yield in Dairy Cows under a Mediterranean Climate. Journal of Dairy Science, 84, 2314-2320. http://dx.doi.org/10.3168/jds.S0022-0302(01)74679-6

[31] Garcia-Ispierto, I., López, G.F., Bech, G.S., Santolaria, P., Yaniz, J., Nogareda, C., De Rensis, F. and Lopez, M.B. (2007) Climate Factors Affecting Conception Rate of High Producing Dairy Cows in Northeastern Spain. Theriogenology, 67, 1379-1385. http://dx.doi.org/10.1016/j.theriogenology.2007.02.009

[32] Henríquez, C., Cabalceta, G., Bertsch, F. and Alvarado, A. (2001) Principales Suelos de Costa Rica. Asociación Costarricense de la Ciencia del Suelo. http://www.mag.go.cr/bibioteca virtual ciencia/suelos-cr.html

[33] Sánchez, J.M. (2001) El valor nutritivo de algunos pastos tropicales de Costa. Programa de Registro y Control de Calidad de Alimentos para Animales Convenio Universidad de Costa Rica (UCR), Ministerio de Agricultura y Ganadería (MAG). http://www.feednet.ucr.ac.cr/bromatologia/pcpt.htm 
Scientific Research Publishing (SCIRP) is one of the largest Open Access journal publishers. It is currently publishing more than 200 open access, online, peer-reviewed journals covering a wide range of academic disciplines. SCIRP serves the worldwide academic communities and contributes to the progress and application of science with its publication.

Other selected journals from SCIRP are listed as below. Submit your manuscript to us via either submit@scirp.org or Online Submission Portal.
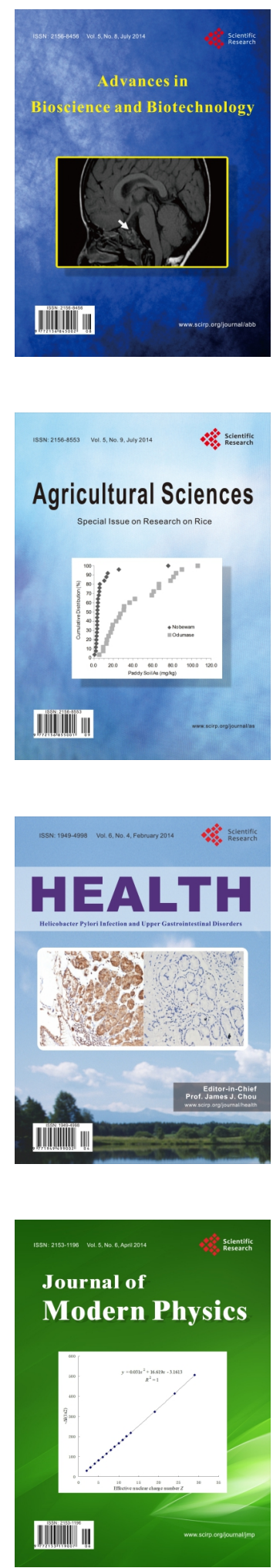
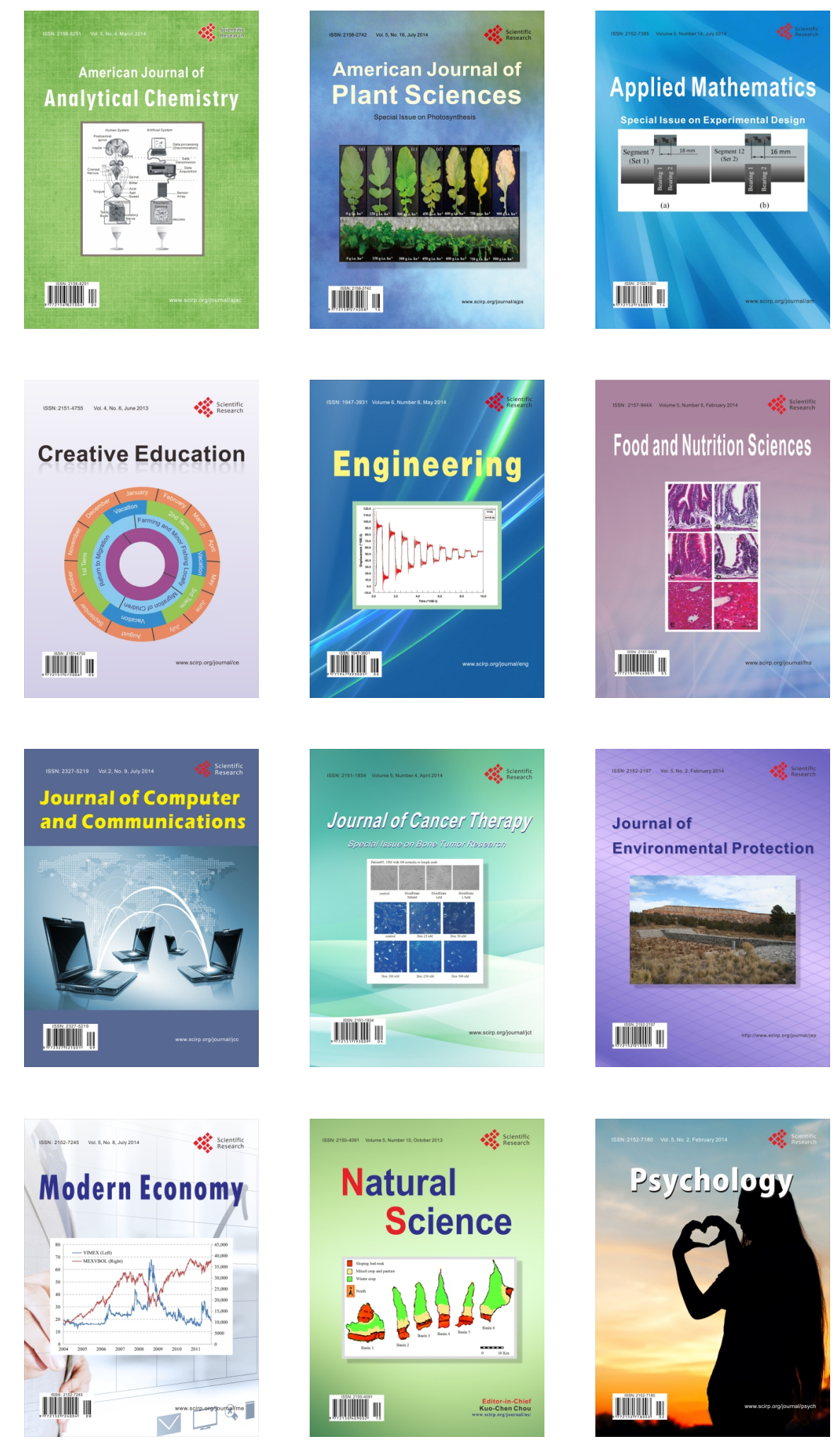